J. Lake Sci. (湖泊科学) , 2019, 31(3): 853-861

DOI 10. 18307/2019. 0323

(c) 2019 by Journal of Lake Sciences

\title{
不同水力调度模式的两座调水型水库轮虫群落结构的比较”
}

\author{
黄 珂, 李慧明,徐少林, 林秋奇**, 韩博平 \\ (暨南大学水生生物研究中心, 广州 510632)
}

\begin{abstract}
摘 要: 为了解水力调度对轮虫群落结构的影响, 于 2016 年 8 月- 2017 年 7 月对调水水源相同而水力调度模式不同的 两座水库 (直流型水库和中等水力滞留时间水库) 的轮虫种类、生物量及环境因子进行逐月观测. 两座水库中共鉴定出轮 虫 37 种, 常见属为臂尾轮属 (Brachionus)、异尾轮属 ( Trichcerca)、龟甲轮属 (Keratella)、三肢轮属 (Filinia) 和多肢轮属 (Polyarthra), 它们的种类数分别占直流型水库和中等水力滞留时间水库所检出轮虫总种类数的 $58 \%$ 和 $64 \%$. 两座水库轮 虫种类虽基本一致, 但轮虫优势种 (相对生物量大于 $10 \%$ ) 有较大差异. 直流型水库轮虫优势种以角突臂尾轮虫 (Brachionus angularis)、镰状臂尾轮虫 (B. falcatus)、裂足臂尾轮虫 (B. diversicornis)、剪形臂尾轮虫 (B. forficula)、截头皱甲 轮虫 (Ploesoma truncatum) 、尖尾疮毛轮虫 (Synchaetidae stylata) 和真翅多肢轮虫 (Polyarthra euryptera) 为主; 中等水力滞留 时间水库主要以卜氏晶囊轮虫 (Asplanchna brightwelli)、裂足臂尾轮虫 (B. diversicornis) 和镰状臂尾轮虫为轮虫优势种. 两 座水库 Bray-Curtis 相异系数为 $0.42 \sim 0.77$, 表明轮虫群落结构差异较大. 圥余分析表明, 叶绿素 a 浓度和温度是影响两座 水库轮虫群落结构的重要因素. 两座水库轮虫群落结构的 Bray-Curtis 相异系数与基于叶绿素 a 浓度和水温的环境欧氏距 离呈显著正相关 $\left(R_{\mathrm{adj}}^{2}=0.426, P<0.05\right)$. 结果表明, 虽然具有相同的调水水源, 但由于两座水库的水力调度不同, 叶绿素 a 浓度和水温有显著差异, 轮虫群落结构趋于相异.
\end{abstract}

关键词: 调水水库;轮虫;多样性;群落结构;相异系数

\section{Comparative analysis of rotifer community structures in two pumped-storage reservoirs with different retention times}

\author{
HUANG Ke, LI Huiming, XU Shaolin, LIN Qiuqi ${ }^{* *}$ \& HAN Boping \\ (Institute of Hydrobiology, Jinan University, Guangzhou 510632, P.R.China)
}

\begin{abstract}
In order to determine the influence of hydraulic regulation and environmental variables on rotifer community structure in pumped-storage reservoirs sharing the same water input but different hydraulic conditions, a through-flowing reservoir and an intermediate retention time reservoir were intensively sampled from August 2016 to July 2017. A total of 37 species of rotifers were identified. Common species in both reservoirs are from the genus Brachionus, Trichocerca, Keratella, Filinia and Polyarthra accounting for $58 \%$ and $64 \%$ of the total rotifer species in the through-flowing reservoir and the intermediate retention time reservoir, respectively. Although the species composition of the two reservoirs are quite similar, the dominant species were different. B. angularis, B. falcatus, B. forficula, B. diversicornis, P. euryptera, Synchaetidae stylata and Ploesoma truncatum dominated in the throughflowing reservoir; while Asplanchna brightwelli, B. diversicornis and B. falcatus dominated in the intermediate retention time reservoir. The Bray-Curtis dissimilarity of rotifer community structure for the two reservoirs is from 0.42 to 0.77 . Redundancy analysis showed that chlorophyll-a and water temperature were the most important environmental variables explaining the variation of rotifer communities in the two reservoirs. The Bray-Curtis dissimilarity was significantly positively correlated with the environmental Euclidean distance based on chlorophyll-a concentration and water temperature $\left(R_{\text {adj }}^{2}=0.426, P<0.05\right)$. The results indicated that although they have the same water input, chlorophyll-a concentration and water temperature are significantly different due to the distinct hydraulic conditions of the two reservoirs resulting to differences in their rotifer community structure.
\end{abstract}

Keywords: Pumped-storage reservoir; rotifer; diversity; community structure; dissimilarity

* 国家自然科学基金项目 (41573062) 和广东省科技计划项目(2016A030313098) 联合资助. 2018-08-18 收稿;201810-29 收修改稿. 黄珂( 1993 ）, 女, 硕士研究生;E-mail:599536546@ qq.com.

** 通信作者;E-mail : tlinqq@ jnu.edu.cn. 
一些水库由于集水面积小, 自产量难以满足用水需求, 需要从临近河流或水库调水补充. 这种依赖调水 来补充库容的水库称为调水水库 ${ }^{[1]}$. 调水水库在我国南方沿海地区较为普遍, 在满足城市供水中起到重要 作用 ${ }^{[2]}$. 调水一般是一种跨流域的调度行为, 其不仅改变了受纳水库的水动力学过程, 也导致了其他流域水 体的营养盐和浮游生物向受纳水库的输人. 调水对受纳水库水动力和营养盐浓度的影响程度取决于调人水 量与受纳水库自产水量的比值, 即调度策略. 如果调人水量远远超过受纳水库的流域自产水量, 则受纳水库 的营养盐浓度主要取决于调人水的营养盐浓度, 而且水力滞留时间相对比较短; 相反, 如果调人水量少于受 纳水库自产水量, 则受纳水库的水动力学过程和营养盐浓度受调水的影响相对较小. 如徐健荣等 ${ }^{[3]}$ 研究发 现, 通过输水渠道串联起来的调水型级联水库, 从第一级水库调水进人下游水库有助于降低下游水库与第 一级水库的环境差异程度. 另外, 调水也将其他流域水体的浮游生物输送到受纳水库中, 并与受纳水库原有 的浮游生物进行竞争, 从而对受纳水库浮游生物群落结构产生影响. 但是, 调水对受纳水库原有浮游生物群 落结构的影响程度取决于调水对受纳水库的营养盐浓度、水动力学过程的影响程度以及各浮游生物类群对 环境变化的敏感程度等因素.

轮虫是淡水浮游动物的主要类群之一, 体型小、繁殖周期短, 具有较高的内禀增长率, 并且具有 $r$-选择型 的生活史类型, 能够在较短时间内占领新的生态位 ${ }^{[4.5]}$. 相比于甲壳类动物, 轮虫能更快地对环境变化作出 响应, 来反映水力调度对浮游动物的影响 ${ }^{[6-8]}$. 水温和食物是影响浮游动物群落结构的重要因素 ${ }^{[9-10]}$. 水温 直接影响浮游动物的生长繁殖, 进而间接影响浮游动物的种群密度 ${ }^{[11]}$; 食物的质量和数量会改变浮游动物 的竞争格局, 而食物的质量和数量又受到水温、氮、磷等非生物因素的影响 ${ }^{[12]}$. 这些环境因素的差异度可用 来反映水力调度对水库环境的影响. 因此, 本文以南亚热带地区具有相同调水水源地而水力调度不同的两 座调水型水库为例, 比较分析两座水库的轮虫种类组成特征及群落结构的差异程度, 探讨水力调度不同而 导致的环境差异是否对轮虫群落结构有影响.

\section{1 材料和方法}

本文研究的两座水库是我国南亚热带地区 (深圳) 典型的调水型水库, 均从东江同一个泵站调水人库, 一座为直流型水库, 另一座为中等水力滞留时间水库. 两座水库相距约 $7 \mathrm{~km}$, 东江水可以直接调人直流型水 库或经中等水力滞留时间水库后进人直流型水库. 直流型水库总库容 4577 万 $\mathrm{m}^{3}$, 平均水深 $11.56 \mathrm{~m}$; 集水区 面积 $60.5 \mathrm{~km}^{2}$, 年降雨量 $2587 \mathrm{~mm}$, 集水区自产水量和从东江调水量分别占水库总供水量的 $4 \%$ 和 $96 \%$. 中等 水力滞留时间水库总库容 1409 万 $\mathrm{m}^{3}$, 平均水深 $5.27 \mathrm{~m}$, 集水面积 $18.6 \mathrm{~km}^{2}$, 年降雨量为 $2287 \mathrm{~mm}$, 集水区自 产水量和从东江调水量分别占水库总供水量的 $23 \%$ 和 $77 \%$. 直流型水库集水区土地利用主要为林地, 中等 水力滞留时间水库集水区土地利用包括农田、果林和村庄等, 存在农业面源污染和农村生活污水排放的 问题.

于 2016 年 8 月- 2017 年 7 月在直流型水库和中等水力滞留时间水库的敞水区最深处 (水深分别为 13 和 $8 \mathrm{~m}$ ) 设置了两个采样点进行逐月采样, 采样时间处于同一时间段 (2017 年 4 月样品缺失). 浮游动物定性 样品使用 $64 \mu \mathrm{m}$ 孔径的浮游生物网于水平及垂直方向进行拖网, 浮游动物定量样品用 $5 \mathrm{~L}$ 的采水器从表层 $0.5 \mathrm{~m}$ 处每隔 $1 \mathrm{~m}$ 采至底部, 当场用孔径 $38 \mu \mathrm{m}$ 的浮游生物网过滤浓缩. 定性和定量样品用 $5 \%$ 福尔马林进 行固定保存. 浮游植物定量样品用采水器于表层 $0.5 \mathrm{~m}$ 处采集水样装于 $350 \mathrm{ml}$ 聚乙烯塑料瓶中, 并加 $1 \%$ 的 鲁哥试剂进行固定保存.

用 YSI6600V2 型多参数水质监测仪现场测定采样点表层 $0.5 \mathrm{~m}$ 的水温 ( Temp) 和 $\mathrm{pH}$, 透明度 $(\mathrm{SD})$ 用塞 氏黑白盘测定,同时采集表层 $0.5 \mathrm{~m}$ 的水样按照国家《地表水环境质量标准》(GB 3838-2002)测定总磷 $(\mathrm{TP})$ 、总氮 $(\mathrm{TN})$ 浓度, 氨氮 $\left(\mathrm{NH}_{3}-\mathrm{N}\right)$ 浓度按照纳氏试剂分光光度法测定, 硝态氮 $\left(\mathrm{NO}_{3}^{-}-\mathrm{N}\right)$ 浓度按照紫外分 光光度法测定, 亚硝态氮 $\left(\mathrm{NO}_{2}^{-}-\mathrm{N}\right)$ 浓度按照分光光度法测定, 溶解性无机氮 (DIN) 浓度通过 $\mathrm{NH}_{3}-\mathrm{N} 、 \mathrm{NO}_{3}^{-}-\mathrm{N}$ 和 $\mathrm{NO}_{2}^{-}-\mathrm{N}$ 求得; 采用反复冻融一浸提法 ${ }^{[13]}$ 测定叶绿素 $\mathrm{a}(\mathrm{Chl} . \mathrm{a})$ 浓度. 水库流域内降雨量、人库流量、出库流 量数据分别由两水库管理处提供. 参考 Koste 分类系统对轮虫进行种类鉴定 ${ }^{[14]}$ 和计数 ${ }^{[15]}$. 计数的同时, 在 显微镜下测量各个体的体长和体宽, 采用近似几何体积计算公式计算轮虫体积, 用近似密度 $1 \mathrm{~g} / \mathrm{cm}^{3}$ 计算生 物量 ${ }^{[15]}$. 当单个轮虫种类生物量超过轮虫总生物量 $10 \%$ 时, 将其定为轮虫优势种类. 浮游植物采用沉淀杯 
法在倒置显微镜下进行鉴定 ${ }^{[16]}$ 与计数 ${ }^{[17]}$. 计数的同时, 在倒置显微镜下测量单个细胞或丝体的体长和体 宽,采用近似几何体积公式计算单个细胞或丝体的体积, 用近似密度 $1 \mathrm{~g} / \mathrm{cm}^{3}$ 计算生物量 ${ }^{[17]}$. 将浮游植物粒 径分为两个数量级, 即粒径 $<20 \mu \mathrm{m}$ 的浮游植物和粒径 $>20 \mu \mathrm{m}$ 的浮游植物.

采用穴余分析 $(\mathrm{RDA})$ 探究环境变量对轮虫群落结构的影响. 在数据处理与分析中, 对轮虫生物量进行 Hellinger 转换, 对环境变量进行对数转化, 采用前向选择剔除不显著环境变量. 运用 Bray-Curtis 相异性指数 比较两座水库轮虫的群落结构相异程度, 对轮虫生物量也进行 Hellinger 转换. 基于前向选择篎选出来的环 境变量计算两座水库的环境变量欧氏距离, 分析两座水库轮虫群落结构相异程度与两座水库环境距离之间 的关系. 在 $\mathrm{R}$ 语言平台上采用 vegan 函数包进行所有的统计分析.

\section{2 结果与分析}

\section{1 环境因子}

直流型水库水力滞留时间除在 2016 年 12 月相对较长 (31 天) 外 (表 1), 其他月份维持在 7 10 天; 中等 水力滞留时间水库水力滞留时间变化幅度不大, 平均为 30 天. 两座水库表层温度为 $17.94 \sim 31.51^{\circ} \mathrm{C}$, 同一月 份表层温度相差 $0.05 \sim 1.55^{\circ} \mathrm{C}$; 配对 $t$ 检验表明, 直流型水库表层水温显著低于中等水力滞留时间水库 $(P<$ $0.05)$, 尤其在夏季. 两座水库 TP、DIN 和 TN 浓度分别为 $0.04 \sim 0.14 \mathrm{mg} / \mathrm{L} 、 0.57 \sim 2.15 \mathrm{mg} / \mathrm{L}$ 和 $1.09 \sim 2.29$ $\mathrm{mg} / \mathrm{L}$; 配对 $t$ 检验表明, 直流型水库 TP 浓度显著低于中等水力滞留时间水库 $(P<0.05)$, 而 DIN 和 TN 浓度 则显著高于中等水力滞留时间水库 $(P<0.001)$. 两座水库透明度变化范围为 $0.40 \sim 2.05 \mathrm{~m}$, 配对 $t$ 检验表明, 直流型水库透明度显著高于中等水力滞留时间水库 $(P<0.001)$. 两座水库的 $\mathrm{pH}$ 为 $6.20 \sim 8.66$, 同一月份相 差 $0.04 \sim 0.72$; 配对 $t$ 检验表明, 直流型水库 $\mathrm{pH}$ 显著低于中等水力滞留时间水库 $(P<0.05)$.

两座水库 Chl.a 浓度为 5.20 63.20 $\mu \mathrm{g} / \mathrm{L}$, 配对 $t$ 检验表明, 直流型水库 Chl. a 浓度显著低于中等水力滞 留时间水库 $(P<0.001)$. 直流型水库除 8 月和 11 月以粒径 $<20 \mu \mathrm{m}$ 的种类占优势 (相对生物量 $>50 \%$ ) 外, 浮 游植物主要以粒径 $>20 \mu \mathrm{m}$ 的种类占优势 (图 1a). 粒径 $>20 \mu \mathrm{m}$ 的浮游植物种类以颗粒直链藻 (Melosira granulata) 和小环藻 (Cyclotella sp.) 为主, 粒径 $<20 \mu \mathrm{m}$ 的主要种类则为卵形隐藻 (Cryptomonas ovata) 和尖尾 蓝隐藻 (Chroomonas acuta) 等. 中等水力滞留时间水库 Chl. a 浓度为 $20.02 \sim 63.20 \mu \mathrm{g} / \mathrm{L}$, 全年以粒径> $20 \mu \mathrm{m}$ 的浮游植物种类占优势 (图 $1 \mathrm{~b}$ ). 粒径 $>20 \mu \mathrm{m}$ 的浮游植物种类主要为丝状的假鱼腥藻 (Pseudoanabaena sp.) 和颗粒直链藻, 粒径 $<20 \mu \mathrm{m}$ 的主要种类则为卵形隐藻.

表 1 直流型水库和中等水力滞留时间水库环境变量以及配对 $t$ 检验结果

Tab.1 Environmental variables of the through-flowing reservoir and the intermediate retention time reservoir and paired $t$-test results

\begin{tabular}{|c|c|c|c|c|c|c|c|c|}
\hline \multirow{2}{*}{ 环境因子 } & \multicolumn{3}{|c|}{ 直流型水库 } & \multicolumn{3}{|c|}{ 中等水力滞留时间水库 } & \multirow{2}{*}{$t$ 值 } & \multirow{2}{*}{$P$} \\
\hline & 最大值 & 最小值 & 平均值 & 最大值 & 最小值 & 平均值 & & \\
\hline 总氮/(mg/L) & 2.29 & 1.72 & 1.98 & 1.94 & 1.09 & 1.65 & 5.15 & $<0.001$ \\
\hline 总磷/ ( mg/L) & 0.09 & 0.04 & 0.64 & 0.14 & 0.06 & 0.08 & -2.38 & $<0.05$ \\
\hline 溶解性无机氮 $/(\mathrm{mg} / \mathrm{L})$ & 2.15 & 1.43 & 1.69 & 1.42 & 0.57 & 1.06 & 6.46 & $<0.001$ \\
\hline 叶绿素 a/ ( $\mu \mathrm{g} / \mathrm{L})$ & 19.80 & 5.20 & 9.81 & 63.20 & 20.02 & 40.10 & -6.72 & $<0.001$ \\
\hline 透明度/m & 2.05 & 0.60 & 1.22 & 0.80 & 0.40 & 0.59 & 5.45 & $<0.001$ \\
\hline 水温 $/{ }^{\circ} \mathrm{C}$ & 31.04 & 17.94 & 24.94 & 31.51 & 18.07 & 25.51 & -2.41 & $<0.05$ \\
\hline 水力滞留时间/d & 31 & 7 & 11 & 36 & 23 & 30 & -8.02 & $<0.001$ \\
\hline $\mathrm{pH}$ & 8.63 & 6.20 & 7.75 & 8.66 & 6.66 & 8.11 & -4.06 & $<0.05$ \\
\hline
\end{tabular}

\section{2 轮虫群落结构}

两座水库共检测到轮虫 9 科 19 属 37 种, 多数种类来自臂尾轮科 (Brachionidae)、异尾轮科 (Trichcercidae) 、疮毛轮科 (Synchaetidae) 和镜轮科 (Testudinellidae), 它们的种类分别占两座水库所检出轮虫总种类数 的 $81 \%$ 和 $85 \%$. 常见属为臂尾轮属 (Brachionus)、异尾轮属 (Trichcerca)、龟甲轮属 (Keratella)、三肢轮属 


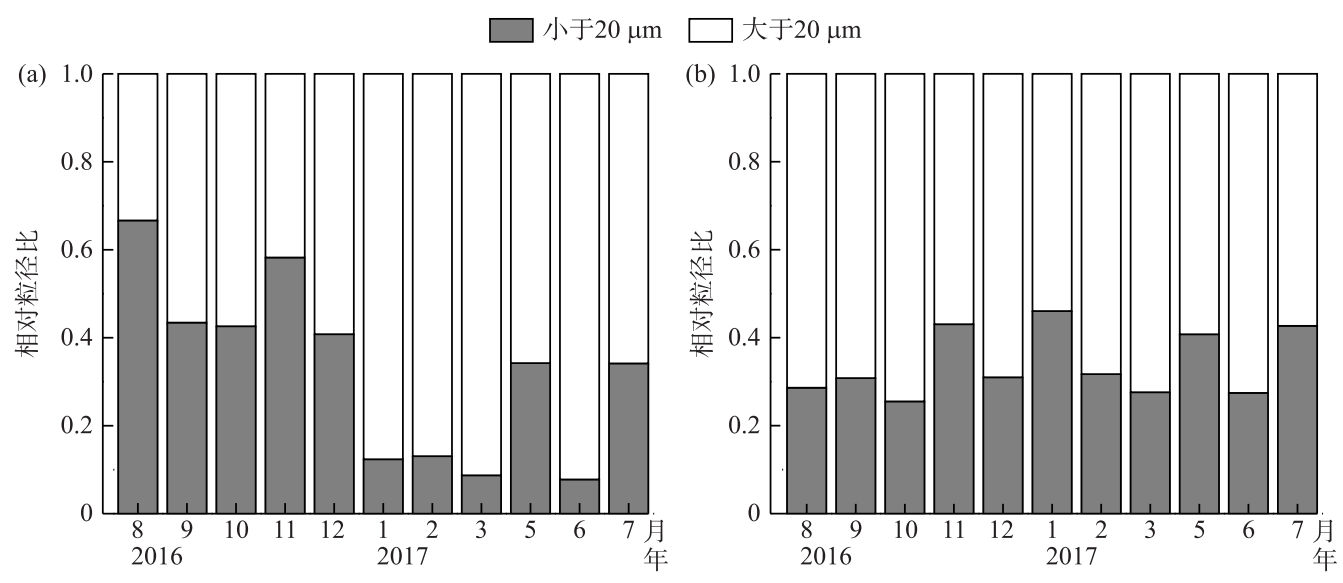

图 1 直流型水库 $(a)$ 和中等水力滞留时间水库 $(b)$ 浮游植物粒径组成的季节动态

Fig.1 Seasonal dynamics of phytoplankton community structure in the through-flowing reservoir (a) and the intermediate retention time reservoir (b)

(Filinia) 和多肢轮属 (Polyarthra), 它们的种类数分别占直流型水库和中等水力滞留时间水库所检出轮虫总 种类数的 $58 \%$ 和 $64 \%$. 两座水库都检测到的轮虫有 32 种, 占总种类数的 $86 \%$. 轮虫种类主要是热带、亚热 带常见种: 角突臂尾轮虫 (B. angularis)、镰状臂尾轮虫 (B. falcatus)、热带龟甲轮虫 ( K. tropica)、螺形龟甲轮 虫 ( $K$. cochlearis) 和对棘异尾轮虫 ( T. stylata) 等.

直流型水库轮虫丰度和生物量分别为 $42 \sim 1048 \mathrm{ind} . / \mathrm{L}$ 和 $17 \sim 726 \mu \mathrm{g} / \mathrm{L}$, 最大值均出现在夏季 9 月, 秋、 冬季则较低 (图 2). 枝角类和桡足类生物量分别为 $33 \sim 2845$ 和 $8 \sim 372 \mu \mathrm{g} / \mathrm{L}$, 平均值分别为 585 和 $86 \mu \mathrm{g} / \mathrm{L}$, 轮虫生物量与枝角类生物量 $\left(R^{2}=0.865, P<0.001\right)$ 和桡足类生物量 $\left(R^{2}=0.862, P<0.001\right)$ 均呈显著正相关. 中等水力滞留时间水库轮虫丰度和生物量分别为 $54 \sim 265 \mathrm{ind} . / \mathrm{L}$ 和 $25 \sim 541 \mu \mathrm{g} / \mathrm{L}$, 在夏季 7 月和秋、冬季 10-11 月均较高, 最小值均出现在 3 月 (图 2). 枝角类和桡足类生物量分别为 9 301 和 1 33 $\mu \mathrm{g} / \mathrm{L}$, 平均值 为 97 和 $13 \mu \mathrm{g} / \mathrm{L}$, 轮虫生物量与枝角类生物量 $\left(R^{2}=0.416, P=0.019\right)$ 和桡足类生物量 $\left(R^{2}=0.426, P=0.018\right)$ 均呈显著正相关.
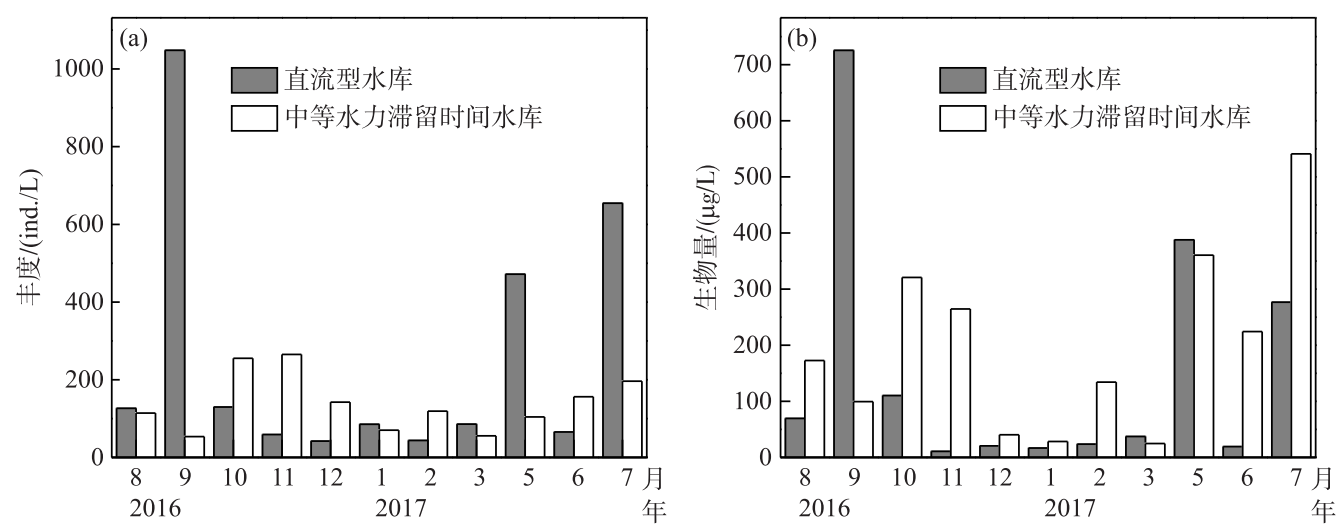

图 2 直流型水库和中等水力滞留时间水库轮虫丰度 (a) 和生物量 (b) 的季节变化

Fig. 2 Seasonal variation of rotifer abundance (a) and biomass (b) in the through-flowing reservoir and the intermediate retention time reservoir

两座水库的轮虫优势种有较大的差异 (图 3). 直流型水库包括角突臂尾轮虫 (B. angularis)、镰状臂尾 
轮虫 (B. falcatus)、裂足臂尾轮虫 (B. diversicornis)、剪形臂尾轮虫 (B. forficula)、截头皱甲轮虫 (Ploesoma truncatum)、尖尾疮毛轮虫 (Synchaetidae stylata) 和真翅多肢轮虫 (P. euryptera) 等优势种, 占轮虫总生物量的 $87 \%$ 以上 (图 3a). 中等水力滞留时间水库的轮虫优势种包括卜氏晶囊轮虫 (Asplanchna brightwelli)、裂足臂 尾轮虫和镰状臂尾轮虫, 占轮虫总生物量的 $90 \%$ 以上 (图 $3 \mathrm{~b}$ ).

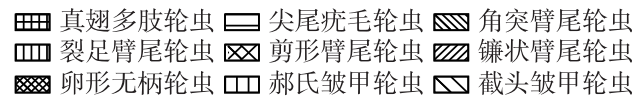

$\square \square$ 独角聚花轮虫 巨圆筒异尾轮虫 $\square$ 其他

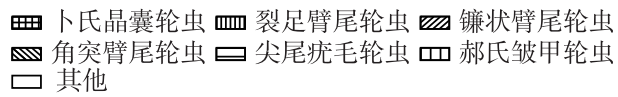

(a)

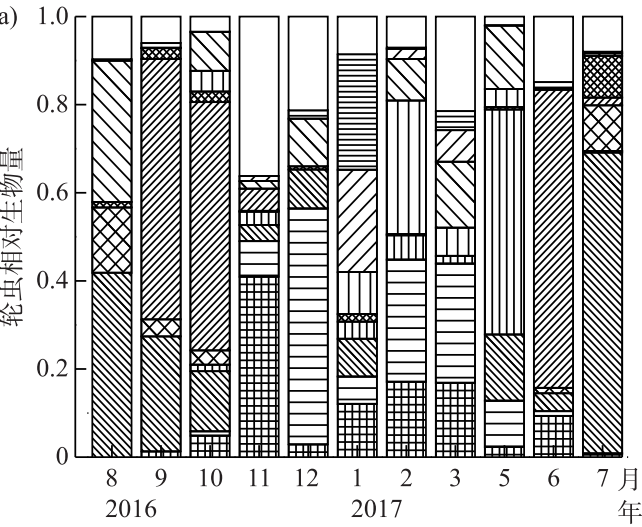

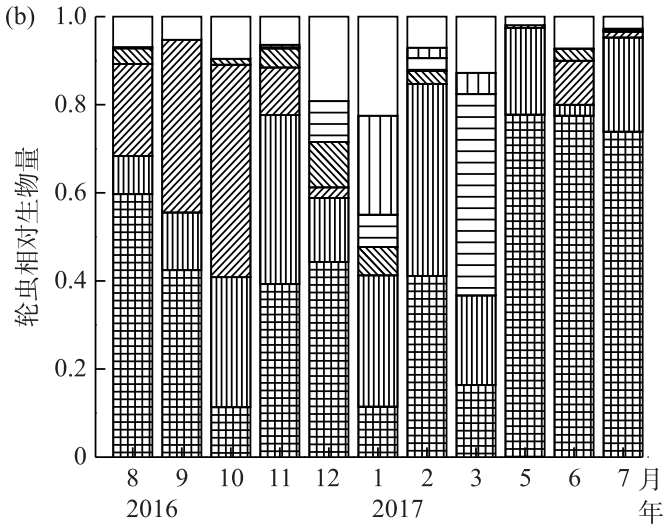

图 3 直流型水库 $(\mathrm{a})$ 和中等水力滞留时间水库 $(\mathrm{b})$ 轮虫群落结构的季节动态

Fig. 3 Seasonal dynamics of rotifer community structure in the through-flowing reservoir (a) and the intermediate retention time reservoir $(\mathrm{b})$

在 TN 浓度、TP 浓度、DIN 浓度、Chl.a 浓度、水温、透明度、水力滞留时间和 $\mathrm{pH}$ 这 8 个变量中, RDA 前向 选择笁选出了水温和 Chl.a 浓度这两个显著的环境变量, 解释了轮虫群落结构变化的 $46 \%\left(R_{\mathrm{adj}}^{2}=0.46, P<\right.$ 0.001 ) (图 4). RDA 图中, 直流型水库各月份样点在第 2 轴的右侧; 中等水力滞留时间水库各月份样点在第 2 轴的左侧. 角突臂尾轮虫、镰状臂尾轮虫和剪形臂尾轮虫的生物量与温度呈正相关, 分布在第 1 轴上侧; 郝 氏坡甲轮虫、截头坡甲轮虫、尖尾疮毛轮虫、真翅多肢轮虫、圆筒异尾轮虫和独角聚花轮虫生物量与温度呈 负相关, 分布在第 1 轴下侧. 裂足臂尾轮虫和卜氏晶囊轮虫生物量与 Chl. a 浓度呈正相关, 分布在第 2 轴的 左侧. 其他轮虫均分布在原点附近.

两座水库间轮虫群落结构的 Bray-Curtis 相异系数为 $0.42 \sim 0.77$, 平均为 $0.59,8$ 月相异系数最高, 3 月相 异系数最低 (图 5a). 基于前向选择篮选出的 Chl.a 浓度和水温这两个环境变量计算了两座水库的环境欧氏 距离. 两座水库 Bray-Curtis 相异系数与环境欧氏距离呈显著正相关关系 $\left(R^{2}=0.426, P=0.017\right)($ 图 $5 b)$.

\section{3 讨论}

调水型水库通过洜站从河流抽水人库, 水体营养盐浓度取决于调人河水水质、水库集水区自产水水质 以及调人水量与水库自产水量的比例. 本研究中, 两座水库虽然具有相同的调水源, 但它们的营养盐浓度差 别比较大, 表明两座水库不仅调人水量与自产水量的比例不同, 而且自产水水质与调人河水水质也不相同. 直流型水库调人的东江水量占水库总进库水量的 $96 \%$, 而且集水区没有农业面源污染, 其营养水平基本上 取决于调人水水质; 中等水力滞留时间水库集水区自产水量占水库总进水量的比例 (23\%) 不仅比直流型水 库高得多,而且水库集水区存在农业面源污染和农村生活污水的排放,自产水对水库水质也会产生一定的 影响. 一般认为, 水力滞留时间影响浮游植物增长率的阈值为 14 天 $^{[18]}$, 低于 14 天时, 高的平流损失率对浮 游植物生物量的累积影响较大; 超过 14 天时, 平流损失率对浮游植物现存量的影响则较小. 中等水力滞留 时间水库水力滞留时间为 $27 \sim 36$ 天, 有利于浮游植物生物量的累积. 直流型水库大部分月份的水力滞留时 


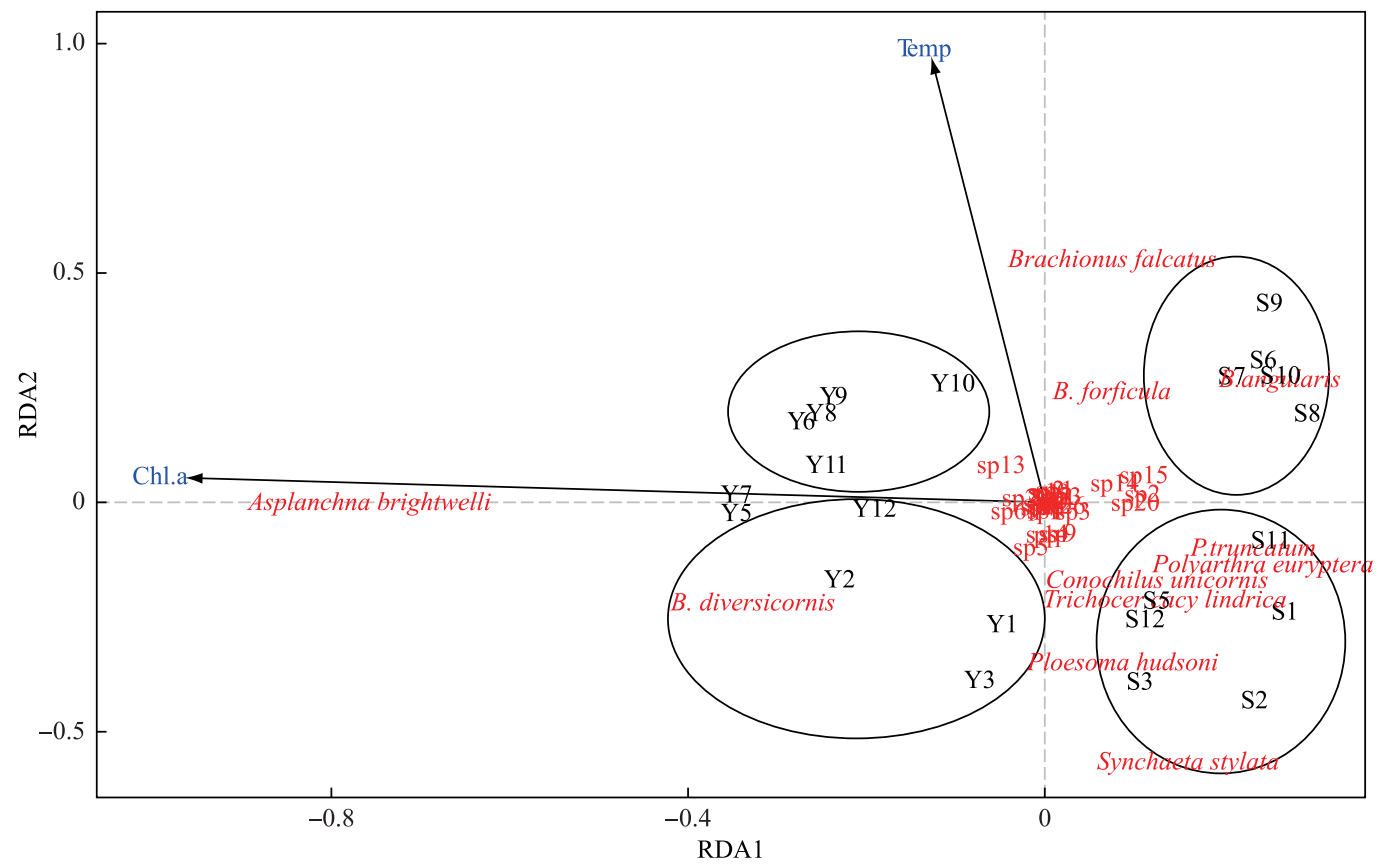

图 4 直流型水库和中等水力滞留时间水库的轮虫群落与环境变量之间的 RDA 分析结果 (黑色字体代表采样点和采样时间,其中 Y 代表中等水力滞留时间水库, $\mathrm{S}$ 代表直流型水库, 数字代表采样时间;红色字体代表轮虫种类;蓝色字体代表环境因子)

Fig.4 RDA analysis between rotifer community and environment variables in the through-flowing reservoir and the intermediate retention time reservoir (black words denote sampling sites and sampling time, Y denotes the intermediate retention time reservoir, $\mathrm{S}$ denotes the through-flowing reservoir, number denotes sampling time; red words denote rotifer species; blue words denote environment factors

间为 7 10 天, 平流损失会降低浮游植物生物量, 由此可以推断, 较短的水力滞留时间也是导致直流型水库 的 Chl.a 浓度低于中等水力滞留时间水库的重要原因.

两座水库均从东江调水,轮虫种类来源一致,因此,两座水库的轮虫种类组成基本没有差别. 在热带亚 热带地区水体中,臂尾轮属、腔轮属、异尾轮属是轮虫种类的主要组成部分 ${ }^{[19]}$. 本文研究的两座水库中臂尾 轮属和异尾轮属的多样性均最高, 体现了热带亚热带水体轮虫组成的特征, 并且与广东省其他水库主要轮 虫种类组成基本一致 ${ }^{[20-21]}$. 分布在同一地区但理化特征 (温度、DIN 浓度、TP 浓度等) 不同的水体, 由于轮虫 种类来源于同一物种库 (东江), 相近水体在种类组成上会存在趋同现象, 但群落结构可能随着环境条件的 变化而呈现不同的群落结构特征. 本次调查的两座水库在轮虫群落结构特征上 Bray-Curtis 相异系数较高, 表明这两座水库轮虫群落结构相异.

温度和食物是影响轮虫种群密度和群落结构的重要生态因子 ${ }^{[22-23]}$. 水温通过改变轮虫食物 (如浮游植 物等) 的种类组成或者食物阈浓度影响轮虫种类间的竞争. Stelzer 研究发现温度和食物阈浓度是调节轮虫 种类竞争的重要因素, 在 $24^{\circ} \mathrm{C}$ 时, 䔅花臂尾轮虫和前节晶囊轮虫的食物阈浓度低于梳状疮毛轮虫, 但种群增 长率高于梳状疮毛轮虫; 相反, 在 $12^{\circ} \mathrm{C}$ 时, 梳状病毛轮虫的食物阈浓度低于蓸花臂尾轮虫和前节晶囊轮虫, 而种群增长率高于臂尾轮虫和晶囊轮虫 ${ }^{[24]}$. 本次调查中, 在温度较高的夏季, 直流型水库中臂尾轮属的丰 度和生物量明显高于其他季节, 而在秋、冬季, 轮虫优势种主要是尖尾疮毛轮虫、截头皱甲轮虫、真翅多肢轮 虫等 (图 3a), 这可能与不同温度条件下轮虫的食物阈浓度有关 ${ }^{[25]}$. 另外, 水温作为关键的非生物因子直接 影响轮虫的生长繁殖, 从而在轮虫群落季节动态变化过程中发挥重要作用. 每种轮虫对温度均有一定的耐 

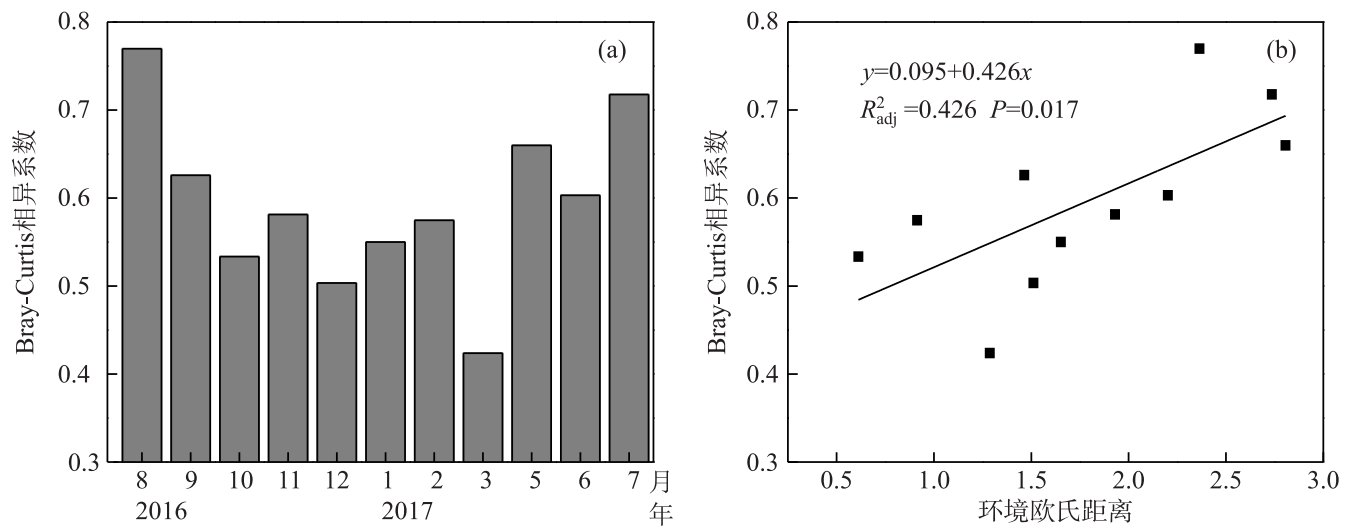

图 5 两座水库轮虫群落 Bray-Curtis 相异系数的季节变化 (a) 以及 Bray-Curtis 相异系数和 基于叶绿素 $\mathrm{a}$ 和水温的环境欧氏距离之间的关系 (b)

Fig.5 Seasonal variations in Bray-Curtis dissimilarity among the two reservoirs (a) and the relationship between Bray-Curtis dissimilarity of rotifer assemblage and the environmental Euclidean distance ( chlorophyll-a and water temperature) (b)

受范围及最适温度, 当达到某种轮虫最适温度时, 轮虫的种群增长率最大, 水温的变化导致不同属轮虫甚至 是同属不同种轮虫发生季节演替 ${ }^{[26]}$. 水温主要通过影响轮虫群落季节动态而间接造成两座水库轮虫群落 结构相异.

虽然轮虫的存活与发育时间总体上随着温度的升高而缩短, 但不同轮虫种类在不同的食物 (如浮游植 物) 种类和浓度情况下存在一定差异 ${ }^{[27-28]}$. 而食物浓度在一定程度上可由 Chl. a 浓度表征, 当 Chl. a 浓度改 变时, 可能会引起属间甚至种间轮虫演替. Pérez-Legaspi 等通过研究不同食物种类和浓度对轮虫种群增长率 的影响得出, 在 $25^{\circ} \mathrm{C}$ 下, 月形腔轮虫 (Lecane luna) 和四齿腔轮虫 (L. quadridentata) 的种群增长率在 $1 \times 10^{6}$ cells $/ \mathrm{ml}$ 的微绿球藻 (Nannochloris oculata) 密度下最高 ${ }^{[29]}$; 颌花臂尾轮虫 (B. calyciflorus) 种群增长率在 $6 \times$ $10^{6} \mathrm{cells} / \mathrm{ml}$ 的斜生栅藻 (Scenedesmus obliquus) 密度下最高 ${ }^{[30]}$; 变形臂尾轮虫 (B. variabilis) 的种群增长率在 $1 \times 10^{6} \mathrm{cells} / \mathrm{ml}$ 的小球藻 (Chlorella sp.) 密度下最高 ${ }^{[31]}$; 当到达轮虫所需的温度和食物浓度时, 该种轮虫能够 迅速生长繁殖成为优势种. 本次调查的两座水库在同一时期 Chl.a 浓度存在较大的差异, 这可能是造成两座 水库轮虫优势种类及生物量有较大差异的重要因素. 直流型水库臂尾轮虫优势种类主要是角突臂尾轮虫和 镰状臂尾轮虫, 而中等水力滞留时间水库臂尾轮虫优势种类主要是裂足臂尾轮虫, 造成两座水库优势臂尾 轮虫的差异可能与 3 种臂尾轮虫食物阈浓度不同有关. 角突臂尾轮虫、镰状臂尾轮虫和裂足臂尾轮虫食物 阈浓度存在差异, 它们之间又存在食物竞争, 水体中食物浓度决定轮虫的竞争格局, 具有低食物阈浓度的轮 虫种类更具优势. 由于目前并没有关于这 3 种臂尾轮虫食物阈浓度的报道, 无法根据食物浓度来判断谁能 取得竞争优势. 食物阈浓度受水温的影响, 温度和食物相互作用共同调控轮虫优势种的演替, 使其竞争格局 发生变化, 进而影响轮虫群落结构. 本研究中裂足臂尾轮虫在食物浓度不同的两座水库均为优势种, 并且在 食物浓度较高的中等水力滞留时间水库为全年优势种, 这可能与裂足臂尾轮虫适宜生长的温度范围 (20 $\left.30^{\circ} \mathrm{C}\right)$ 和食物浓度范围 $\left(1 \times 10^{6} \sim 5 \times 10^{6} \mathrm{cells} / \mathrm{ml}\right)$ 较广有关 ${ }^{[32-33]}$.

由于不同种类轮虫口器和头冠类型的差异, 它们能够摄食的食物颗粒大小不同 ${ }^{[33]}$. 采用槌型咀嚼器和 须足轮虫型头冠的臂尾轮虫一般只能滤食小于 $20 \mu \mathrm{m}$ 的食物颗粒; 而采取砧型或杖型咀嚼器、晶囊轮虫型 头冠的晶囊轮虫、多肢轮虫、疮毛轮虫和异尾轮虫等能进行选择性摄食, 不容易受丝状藻类的干扰 ${ }^{[34-35]}$. 由 于直流型水库在温度较高的月份 (如 $8-10$ 月) 小于 $20 \mu \mathrm{m}$ 的浮游植物所占比例相对较高, 轮虫以臂尾轮虫 为主要优势种类; 相反, 当大于 $20 \mu \mathrm{m}$ 浮游植物为优势类群时, 圆筒异尾轮虫、尖尾疮毛轮虫、真翅多肢轮虫 和郝氏皱甲轮虫等成为优势种类. 中等水力滞留时间水库全年以大于 $20 \mu \mathrm{m}$ 浮游植物为优势类群, 由于卜 
氏晶囊轮虫为杂食性轮虫, 不仅摄食浮游植物, 还可以摄食小型浮游动物, 不受丝状蓝藻的影响, 在水库中 为全年优势种. 综上所述, 水温和食物共同调节轮虫群落结构, 相比水温而言, 食物对两座水库轮虫群落结 构的影响更大.

由于轮虫进行孤雌生殖, 个体发育时间较短, 种群增长速率较快, 相对来说, 轮虫种群增长率要高于枝 角类和桡足类, 受平流损失影响较小, 比较容易在水力滞留时间较短的水库中成为优势种群 ${ }^{[36]}$. 由于食物 生态位有部分重叠, 桡足类和枝角类是水体中轮虫食物的主要竞争者. 本次调查中, 两座水库的轮虫生物量 与枝角类生物量和桡足类生物量均呈显著正相关, 这说明它们的生物量随时间的动态变化基本一致, 轮虫 与枝角类和桡足类之间的食物竞争并不是造成两座水库轮虫群落结构季节变化的主要因素. 虽然两座水库 从同一河流调水, 但由于水力调度不同, 造成两座水库水动力学条件和其他环境条件差异显著, 从而影响轮 虫的食物数量和质量及轮虫优势种演替, 进而影响轮虫的季节动态及群落结构, 造成两座水库轮虫群落结 构差异较大.

\section{4 参考文献}

[ 1 ] Straškraba M, Tundisi JG. Reservoir water quality management. International Lake Environment Committee, United Nations Environment Programme, 1999.

[ 2 ] Lin ZW, Gu JG, Han BP. Spatial distribution of sediments and contents of inorganic phosphorus in a pumped storage reservoir. Journal of Agro-Environment Science, 2006, 25(3): 776-781. [ 林彰文, 顾继光, 韩博平. 一个抽水水库的沉积 物及其无机磷含量的分布特点. 农业环境科学学报, 2006, 25(3) : 776-781.]

[ 3 ] Xu JR, Qiao L, Han BP et al. Response of cladoceran assemblage to inter-basin water transfer in cascading pump reservoir systems. Chin J Appl Environ Biol, 2016, 22(2): 313-319. [徐健荣, 乔否, 韩博平等. 级联调水水库系统枝角类群 落结构对调水的响应. 应用与环境生物学报, 2016, 22(2): 313-319.]

[ 4 ] Branco CWC, Senna PAC. Relations among heterotrophic bacteria, chlorophyll-a, total phytoplankton, total zooplankton and physical and chemical features in the Paranoa reservoir, Brasilia, Brazil. Hydrobiologia, 1996, 337 ( 1/2/3) : 171-181.

[ 5 ] Duggan IC, Green JD, Shiel RJ. Distribution of rotifers in North Island, New Zealand, and their potential use as bioindicators of lake trophic state. Hydrobiologia, 2001, 446/447(1) : 155-164.

[ 6 ] Branco CWC, Rocha MIA, Pinto GFS et al. Limnological features of Funil Reservoir (R.J. Brazil) and indicator properties of rotifers and cladocerans of the zooplankton community. Lakes \& Reservoirs Research \& Management, 2002, 7 ( 2): $87-92$.

[ 7 ] Souza LCE, Branco CWC, Domingos P et al. Zooplankton of an urban coastal lagoon: composition and association with environmental factors and summer fish kill. Zoologia, 2011, 28(3) : 357-364.

[ 8 ] Ejsmont-Karabin J. The usefulness of zooplankton as lake ecosystem indicators: Rotifer trophic state index. Polish Journal of Ecology, 2012, 60(2) : 339-350.

[ 9 ] Lin QQ. Species diversity and spatial and temporal variations of pelagic metazooplankton in Liuxihe Reservoir. Guangzhou: Jinan University, 2007. [ 林秋奇. 流溪河水库后生浮游动物多样性与群落结构的时空异质性 [学位论文]. 广州: 暨 南大学, 2007.]

[10] Iglesias C, Mazzeo N, Meerhoff M et al. High predation is of key importance for dominance of small-bodied zooplankton in warm shallow lakes: evidence from lakes, fish exclosures and surface sediments. Hydrobiologia, 2011, 667 (1) : 133-147.

[11] Beisner BE, Mccauley E, Wrona FJ. The influence of temperature and food chain length on plankton predato. Canadian Journal of Fisheries \& Aquatic Sciences, 1997, 54: 586-595.

[12] Sarma SSS, Nandini S, Gulati RD. Life history strategies of cladocerans: comparisons of tropical and temperate taxa. Hydrobiologia, 2005, 542(1) : 315-333.

[13] Lin SJ, He LJ, Huang PS et al. Comparison and improvement on the extraction method for chlorophyll-a in phytoplankton. Ecologic Science, 2005,24(1): 9-11. [ 林少君, 贺立静, 黄沛生等. 浮游植物中叶绿素 a 提取方法的比较与改进. 生 态科学, 2005, 24(1): 9-11.]

[14] Koste W ed. Rotatoria. Berlin: GebrÜder Borntraege, 1978.

[15] Zhang ZX, Huang XF eds. Freshwater plankton research method. Beijing: Science Press, 1991.[章宗涉, 黄祥飞. 淡水 
浮游生物研究方法. 北京: 科学出版社, 1991.]

[16] Hu HJ, Wei YX eds. The freshwater algae of china-systematics, taxonomy and ecology. Beijing: Science Press, 2006. [ 胡 鸿钧, 魏印心. 中国淡水藻类——系统、分类及生态. 北京: 科学出版社, 2006.]

[17] Hillebrand H, Dürselen CD, Kirschtel D. Biovolume calculation for pelagic and benthic microalgae. Journal of Phycology, 1999, 35(2) : 403-424.

[18] Kasprzak P, Padisák J, Koschel R et al. Chlorophyll-a, concentration across a trophic gradient of lakes: An estimator of phytoplankton biomass. Limnologica, 2008, 38(3) : 327-338.

[19] Segers H. Zoogeography of the Southeast Asian Rotifera. Hydrobiologia, 2001, 446/447 (1) : 233-246.

[20] Lin QQ, Zhao SY, Han BP. Rotifer distribution in tropical reservoirs, Guangdong Province, China. Acta Ecologica Sinica, 2005, 25(5): 1123-1131. [ 林秋奇, 赵帅营, 韩博平. 广东省水库轮虫分布特征. 生态学报, 2005, 25 (5)： 1123-1131.]

[21] Chen LG, Lin QQ, Han BP. Dynamics and community structure of Rotifers in Xikeng Reservoir, south China. Journal of Hydroecology, 2013, 34(6): 27-33. [陈丽光, 林秋奇, 韩博平. 茜坑水库轮虫群落结构组成和动态. 水生态学杂 志, 2013, 34(6) : 27-33.]

[22] Moore MV, Folt CL, Stemberger RS. Consequences of elevated temperatures for zooplankton assemblages in temperate lakes. Archiv fur Hydrobiologie, 1996, 135(3) : 289-319.

[23] Baião C, Boavida MJ. Environmental factors determining the structure of rotifer communities in a river-shed reservoir. Aquatic Ecology, 2000, 34(4) : 369-377.

[24] Stelzer CP. Population growth in planktonic rotifers. Does temperature shift the competitive advantage for different species? Hydrobiologia, 1998, 387/388: 349-353.

[25] Arora J, Mehra NK. Seasonal dynamics of rotifers in relation to physical and chemical conditions of the river Yamuna (Delhi), India. Hydrobiologia, 2003, 491(1/2/3): 101-109.

[26] Herzig A. The analysis of planktonic rotifer populations: A plea for long-term investigations. Hydrobiologia, 1987, 147 (1) : 163-180.

[27] Xi YL, Ge YL, Chen F et al. Life history characteristics of three strains of Brachionus calyciflorus ( Rotifera) at different temperatures. Journal of Freshwater Ecology, 2005, 20(4) : 707-713.

[28] Ma Q, Xi YL, Zhang JY et al. Differences in life table demography among eight geographic populations of Brachionus calyciflorus (Rotifera) from China. Limnologica, 2010, 40(1) : 16-22.

[29] Pérez-Legaspi IA, Rico-Martínez R. Effect of temperature and food concentration in two species of littoral rotifers. Hydrobiologia, 1998, 387/388: 341-348.

[30] Xi YL, Dong LL, Ge YL et al. Resting egg production of Brachionus calyciflorus (Rotifera) at different water temperatures. Journal of Freshwater Ecology, 2004, 19(4) : 567-573.

[31] Sarma SSS, Nandini S. Life table demography and population growth of Brachionus variabilis Hempel, 1896 in relation to Chlorella vulgaris densities. Hydrobiologia, 2001, 446/447(1) : 75-83.

[32] Ma J, Xi YL, Xu DD et al. Effects of temperature and algal density on life history characteristics and morphotype in offspring of two Brachionus diversicornis morphotypes. J Lake Sci, 2011, 23(4) : 597-604. DOI: 10.18307/2011.0416. [马 杰, 席贻龙, 许丹丹等. 温度和食物密度对两种形态型裂足臂尾轮虫 (Brachionus diversicornis) 生活史特征和后代 形态型的影响. 湖泊科学, 2011, 23(4): 597-604.]

[33] Ning LF, Xi YL, Sun Q et al. Combined effects of temperature and algal food density on life table demography of Brachionus diversicornis (Rotifera). J Lake Sci, 2013, 25(2) : 295-301. DOI: 10.18307/2013.0218. [宁乐锋, 席贻龙, 孙强 等. 温度和食物密度对裂足臂尾轮虫 (Brachionus diversicornis) 生命表统计学参数的影响. 湖泊科学, 2013, 25(2): 295-301.]

[34] Virro T, Haberman J, Haldna M et al. Diversity and structure of the winter rotifer assemblage in a shallow eutrophic northern temperate Lake Võrtsjärv. Aquatic Ecology, 2009, 43(3) : 755-764.

[35] Spoljar M, Habdija I, Primc-Habdija B et al. Impact of environmental variables and food availability on rotifer assemblage in the karstic barrage Lake Visovac (Krka River, Croatia). International Review of Hydrobiology, 2005, 90 (5/6): 555-579.

[36] DeMott WR. The role of competition in zooplankton succession // Sommer U ed. Plankton ecology. Springer, 1989: 195-252. 